Yellow Stars and Ice 
Princeton Series of Contemporary Poets David Wagoner, Editorial Adviser

OTHER BOOKS IN THE SERIES

Returning Your Call, by Leonard Nathan

Sadness And Happiness, by Robert Pinsky

Burn Down the Icons, by Grace Schulman

Reservations, by James Richardson

The Double Witness, by Ben Belitt

Night Talk and Other Poems, by Richard Pevear

Listeners at the Breathing Place, by Gary Miranda

The Power to Change Geography, by Diana Ó Hehir

An Explanation of America, by Robert Pinsky

Signs and Wonders, by Carl Dennis

Walking Four Ways in the Wind, by John Allman

Hybrids of Plants and of Ghosts, by Jorie Graham

Movable Islands, by Deborah Greger 


\section{Yellow Stars and Ice}

\section{by Susan Stewart}

Princeton University Press

Princeton, New Jersey 
Copyright (C) 1981 by Princeton University Press

Published by Princeton University Press, Princeton, New Jersey

In the United Kingdom: Princeton University Press, Guildford, Surrey

All Rights Reserved

Library of Congress Cataloging in Publication Data will be found on the last printed page of this book

Publication of this book has been aided by a grant from the Paul Mellon Fund of Princeton University Press

This book has been composed in Linotron Trump

Clothbound editions of Princeton University Press books are printed on acid-free paper, and binding materials are chosen for strength and durability

Printed in the United States of America by Princeton University Press, Princeton, New Jersey 


\section{For Daniel Halevy}

"N'apaisons pas le jour et sortons la face nue

face aux pays inconnus qui coupent aux oiseaux leur sifflet ..."

Aimé Césaire, Cadastre 
